\title{
In vitro evaluation of gingival fibroblasts proliferation and smear layer formation in pre-conditioned root surfaces
}

\author{
Avaliação in vitro do comportamento biológico de fibroblastos gengivais em superfícies radiculares \\ pré-condicionadas
}

\author{
Nayce Melinda Ferreira LIMA' \\ Daiane Cristina PERUZZO' \\ Fabrício Passador-SANTOS ${ }^{1}$ \\ Eduardo SABA-CHUFJI ${ }^{1}$ \\ Elizabeth Ferreira MARTINEZ'
}

\section{ABSTRACT}

\section{Objective}

The objective of the present study was to evaluate, in vitro, fibroblastic proliferation on chemically conditioned root surfaces.

\section{Methods}

Forty single-rooted human teeth, were cut into fragments and divided into four groups ( $n=20)$ : $G$ l (control) - scaling and root planing (SRP); GII - SRP + conditioning with $10 \%$ citric acid; GIII - SRP + conditioning with $24 \%$ EDTA gel and GIV - SRP + conditioning with 50 mg/m/ of tetracycline hydrochloride. The fibroblasts were placed on these surfaces and cell proliferation evaluated using Trypan Blue stain. Smayer layer formation was analyzed using Scanning Electron Microscopy.

\section{Results}

The results revealed that the chemical conditioners used were incapable of effectively removing the smear layer. However, when compared to the other groups, GIII showed the best results regarding removal of the smear layer $(p<0.05)$. Gl demonstrated the greatest cell proliferation at all studied time intervals compared to the chemically treated groups $(p<0.05)$.

\section{Conclusion}

The results of the present study reveal that all demineralizing agents evaluated presented lower cell proliferation levels when compared to the control group. In addition none of the chemical conditioners used removed the smear layer completely.

Indexing terms: Chemical treatment. Periodontal debridment. Periodontal disease.

\section{RESUMO}

Objetivo

Avaliar in vitro a proliferação de fibroblastos em superfícies radiculares, previamente condicionadas quimicamente.

\section{Métodos}

Para este estudo, 40 dentes unirradiculares humanos hígidos, extraídos por acometimento periodontal irreversível, foram seccionados em fragmentos radiculares e divididos em 04 grupos (20 espécimes/grupo) de acordo com a aplicação do condicionamento ácido: GI (controle) apenas submetidos à raspagem e alisamento radicular (RAR); GII - RAR + condicionamento com ácido cítrico a 10\%; GIII-RAR + condicionamento com gel de EDTA a 24\%, ph 7,0; e GIV- RAR + condicionamento com 50mg/ml de cloridrato de tetraciclina. Adicionalmente, as células foram plaqueadas sobre estas superfícies e foi avaliada a proliferação celular por meio do corante vital azul de Trypan. Para a análise da morfologia ultraestrutural foi utilizado Microscopia Eletrônica de Varredura (MEV).

\section{Resultados}

Os resultados demonstraram que em relação à proliferação celular, os condicionadores químicos utilizados não foram capazes de remover efetivamente a smear layer. Entretanto, no grupo tratado com EDTA (GIII) foi observado uma maior remoção $(P<0,05)$ na quantidade de smear layer quando comparado aos demais grupos. No grupo controle (GI) pode-se observar uma maior proliferação celular em todos os tempos $(24 \mathrm{~h}, 48 \mathrm{~h}, 72 \mathrm{~h})$ quando comparado aos demais grupos que sofreram tratamento químico $(\mathrm{P}<0,05)$.

\section{Conclusão}

Considerando os agentes desmineralizantes avaliados, a maior remoção de smear layer e proliferação celular foram alcançados com o gel de EDTA a $24 \%$, quando comparado ao grupo condicionado com cloridrato de tetraciclina $50 \mathrm{mg} / \mathrm{ml}$, após 72 horas de cultivo celular.

Termos de indexação: Processos químicos. Desbridamento periodontal. Doenças periodontais.

\footnotetext{
${ }^{1}$ Faculdade São Leopoldo Mandic, Curso de Odontologia, Programa de Pós-Graduação em Odontologia. Rua José Rocha Junqueira 13, Swift, 13045755, Campinas, SP, Brasil. Correspondência para / Correspondence to: EF MARTINEZ. E-mail: <dr.efmartinez@gmail.com>.
} 


\section{INTRODUCTION}

Periodontal disease is characterized by a chronic inflammatory process, in which the main agent is the bacterial biofilm ${ }^{1-2}$. Its progression is associated to subgingival bacterial colonization ${ }^{2}$, whose toxins are absorbed and fixed to the cement surface ${ }^{3}$, acting as a barrier to the attachment of periodontal tissues ${ }^{2-6}$, consequently promoting irritation, collagen fiber degradation ${ }^{3}$, progressive alveolar bone, cement and periodontal ligament destruction ${ }^{7}$.

Root surface conditioning of a tooth affected by periodontal disease aims to remove dental calculus, bacterial biofims and their toxins ${ }^{2,8-9}$, which consequently contributes to a reduced inflammatory process, periodontal tissue repair ${ }^{10-12}$ including formation of new supporting tissues ${ }^{12-14}$. However, mechanical debridement procedures are known to create a layer of organic, mineralized waste, also known as smear layer, which covers the prepared root surface and obstructs the dentinal tubules ${ }^{14-15}$, serving as substrate for bacterial growth and making periodontal attachment to the root surface more difficult ${ }^{11}$.

Therefore, an alternative method to remove the smear layer is the combination of debridment and chemical root conditioning, which may be capable of decontaminating, detoxifying and demineralizing the root surface, thus opening the dentinal tubules and exposing the collagen matrix $x^{2,11-14,16}$, which is fundamental for recolonization of cells involved in periodontal repair, 10-12,14, promoting a urface that is biologically compatible with

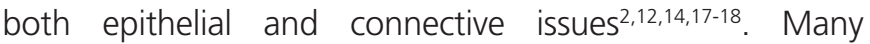
substances have been used with this objective in mind, mainly in solution form, including citric acid, tetracycline and ethylenediaminetetraacetate acid (EDTA) ${ }^{13}$.

Citric acid was the first chelating agent to be used $^{19}$. It features antimicrobial action ${ }^{10,19-20}$, promotes superior fibrin interlinking ${ }^{20}$ and intensifies mesenchymal cell adhesion via biochemical mechanisms ${ }^{11}$, accelerating cementogenesis ${ }^{12,14}$. However, high concentrations of this chemical conditioner must be avoided ${ }^{5}$, since an extremely acidic $\mathrm{pH}$ results in necrosis, denatured collagen and unfavorable periodontal repair on adjacent tissues ${ }^{18}$.

Tetracycline hydrochloride (TTC-HCl) is another chemical conditioner that increases extracellular matrix protein bond to dentin, and stimulates growth and fibroblast fixation $^{4-5,11}$. In addition, it increases the effectiveness of fibronectin, a collagenase inhibitor ${ }^{21}$ and it also features presenting anti-inflammatory ${ }^{19}$ as well as antibacterial properties $^{5,12}$, all of which are maintained for between 48 hours and 14 days $^{4,21}$, due to adsorption and slow release by dentin ${ }^{4}$.

Regarding an alternative to low $\mathrm{pH}$ conditioners, EDTA is a chelating agent with a neutral $\mathrm{pH}^{11,14}$ that is bactericidal $^{7}$ and exerts a demineralizing effect ${ }^{5}$, exposing the dentin matrix proteins without changing the biochemical and structural properties of the periodontal tissues $2,12,17$.

Therefore, the present study aimed to evaluate, in vitro, the structural morphology of root surfaces conditioned with 10\% citric acid gel, 24\% EDTA gel, and 50mg/ $\mathrm{ml}$ tetracycline hydrochloride, as well as to compare the proliferation of human fibroblasts cultivated on these surfaces.

\section{METHODS}

\section{Selection and preparation of specimens}

This study was approved by the Research Ethics Committee of São Leopoldo Mandic University, Campinas, SP, Brazil (no. 2009/0083).

Forty single-root human teeth with advanced periodontal disease were obtained for this study. The patients selected in this study presented generalized chronic periodontitis (20), with more than $30 \%$ of sites showing concomitant probing depth (PD) and clinical attachment level $(C A L) \geq 4 \mathrm{~mm}$ and, at least one tooth requiring extraction due to advanced periodontitis [sites with PD and CAL $>7 \mathrm{~mm}$ with bleeding on probing (BoP) and mobility]. Following extraction, the teeth were rinsed in distilled water in order to remove organic debris and stored at $4^{\circ} \mathrm{C}$ in $0.1 \%$ Thymol (LAFAN ${ }^{\circledR}$, Várzea Paulista, São Paulo, Brazil). Once all samples were obtained, they were submitted to scaling and root planing (Gracey 5/6 curettes, São Paulo, Brazil) by an experienced, trained and calibrated professional (NMFL). The crowns were removed $2 \mathrm{~mm}$ below the cementoenamel junction, using an ISOMET 1000 (Buehler ${ }^{\circledR}$, Illinois, USA) saw. The root was then cut longitudinally into $8010 \mathrm{~mm}$ (length) by $2 \mathrm{~mm}$ (width) fragments.

The specimens were sterilized in an autoclave (Cristófoli, Brazil) and randomly divided into four groups ( $n=20)$ according to the acid conditioner to be applied to the root surface: GI (control) were submitted to scaling and root planing (SRP) only; GIl underwent SRP and conditioning with $10 \%$ citric acid; GIII - SRP, as well as conditioning with 24\% EDTA gel, pH 7.0; and GIV - SRP with conditioning using $50 \mathrm{mg} / \mathrm{ml}$ tetracycline hydrochloride capsules, all commercially avaiable.

The conditioning agents were applied to the root 
surface for three minutes, creating mechanical friction using a sterile swab. All specimens were then rinsed in $10 \mathrm{ml}$ of sterile $\mathrm{pH} 7.4$ phosphate buffered saline (PBS) and used for the following experiments.

\section{Structural root analysis (Scanning Electron Microscopy)}

Eight scaled root fragments were used for this stage, either with or without conditioning with the different demineralizing agents. Scanning Electron Microscopy (SEM) was used to analyze the root structure. The specimens were fixed in 4\% Formaldehyde / $0.1 \mathrm{M}$ Glutaraldehyde Cacodylate Buffer, pH 7.4, for one hour at room temperature, rinsed in the buffered solution and dehydrated to critical point in successive HMDS. The specimens were then mounted on metal platforms (stubs) before analyzing their morphological structure using SEM (Jeol 6100 USA Inc., Peabody, MA, USA). These analyses were performed by a trained examiner blinded to the treatment groups.

\section{Cell culture}

Fibroblasts from the gingival mucosa were obtained from explants of healthy human attached gingiva. The cells were then cultured in Dulbecco's modified Eagle's medium (DMEM) (Sigma, St Louis, MO, USA) supplemented with $1 \%$ antimycotic solution (Sigma), containing 10\% fetal bovine serum (Cultilab, Campinas, SP, Brazil). The cultures were incubated at $37{ }^{\circ} \mathrm{C}$ in a humidified environment (5\% CO2 / 95\% air), and assessed every 24 hours. Once the cells reached subconfluence, they were harvested with trypsin and then subcultured. The fibroblast cell cultures used in the following procedure were from passages three to six for all experiments.

\section{Cell proliferation assay}

For the proliferation test, cells were grown on 24 well plates (Corning, NY, USA) at an initial density of 110 cells/mm2 per well on the root surfaces. After 24, 48 and 72 hours, cells from three randomly selected wells were detached using $0.05 \%$ trypsin and counted in a Neubauer chamber in order to calculate proliferation indices.

\section{Statistical Analysis}

Data relating to cell proliferation were analyzed regarding the assumptions of a normal distribution and equality of variance and were submitted to two-way analysis of variance (ANOVA) and the Tukey test. Statistical calculations were performed using SPSS 20 (SPSS Inc., Chicago, IL, USA), with a $5 \%$ significance being adopted for all analyses.

\section{RESULTS}

\section{Scanning Electron Microscopy Analysis}

Morphological analysis was performed on the central cervical region of the root fragments. The control group $(\mathrm{Gl})$ showed little exposure of the dentinal tubules, due to the presence of a smear layer (Figure 1A), when compared with the citric acid (GII, Figure 1B) and EDTA (GIII, Figure 1C) groups. However, the citric acid group (Figure 1B) also showed low exposure of dentinal tubules due to a smear layer when compared with the EDTA group (Figure 1C), which demonstrated higher exposure than the other groups. A large quantity of substance residue was observed covering the dentinal tubules in the tetracycline hydrochloride group (GIV, Figure 1D).

\section{Cell Proliferation Assay}

Analysis of variance revealed a significant interaction between the type of treatment received and time $(p<0,001)$. At 24 hours, there was no significant difference in cell proliferation, regardless of the treatment applied (10\% Citric Acid, $24 \%$ EDTA, or $50 \mathrm{mg} / \mathrm{ml}$ Tetracycline Hydrochloride) to the root fragment (Table 1 e Figure 2). However, at 48 hours cell proliferation in groups II, III and IV was significantly lower than observed for group I. After 72 hours, cell proliferation for group I was also significantly higher compared to the other groups. When comparing groups II, III and IV only, group III presented a fibroblast count that was significantly higher than that of group IV, while group II did not demonstrate a significant difference compared to group III ( $p>0.05$ ) (Table 1 and Figure 2).

In addition, when the root fragment was subjected to treatment with $10 \%$ Citric Acid, $24 \%$ EDTA gel or 50 $\mathrm{mg} / \mathrm{ml}$ Tetracycline Hydrochloride, there was no significant difference $(p>0.05)$ in fibroblast proliferation over time (Table 1 and Figure 1). However, in the absence of surface conditioning, the fibroblast count was significantly higher $(p<0.05)$ after 72 hours, intermediate after 48 hours and lower after 24 hours (Table 1 and Figure 1).

\section{DISCUSSION}

Over the years, scaling and root planning has been proposed to promote a biocompatible root surface for the adjacent periodontal tissues ${ }^{10,21-22}$. However, this conventional approach produces a fine smear layer over the root surface, which may compromise tissue healing $g^{5,8,10}$. 
Therefore, the combination of chemical and mechanical treatments to the root surface has been suggested to decontaminate and remove the smear layer ${ }^{10-11}$, decalcify the root surface, and expose the dentin collagen matrix, aiding in the formation of a new connective tissue fiber attachment ${ }^{5,8,11}$. In the present study, one may observe that when compared to the other groups, the application of $24 \%$ EDTA for three minutes achieved an increased dentinal tubule exposure, with a larger diameter, due to a significant, though not complete, removal of the smear layer. Similarly, other studies have demonstrated a demineralized root surface when using 24\% EDTA for three minutes ${ }^{22}$ with removal of the smear layer and exposure of the dentin matrix ${ }^{16}$. Many studies have shown that co-treatment with citric acid for two minutes results in exposure of the dentin tubules, leading to intertubular dentin surface porosity, which corresponds to exposed collagen fibers and proteoglycans ${ }^{7,16,10}$. In the present study citric acid at $10 \%$ was used demonstrating a capacity to expose root surface collagen, similarly to Blomlof and coworkers study ${ }^{5}$ On the other hand Fontanari et al. ${ }^{22}$ used a $1 \%$ citric acid solution for 1 minute and were not able to demonstrate effective demineralization when applying it to the root surface. However, in this study, the group in which 10\% citric acid was used for three minutes presented a greater dentin tubule exposure when compared to the control group, despite an incomplete removal of the smear layer.
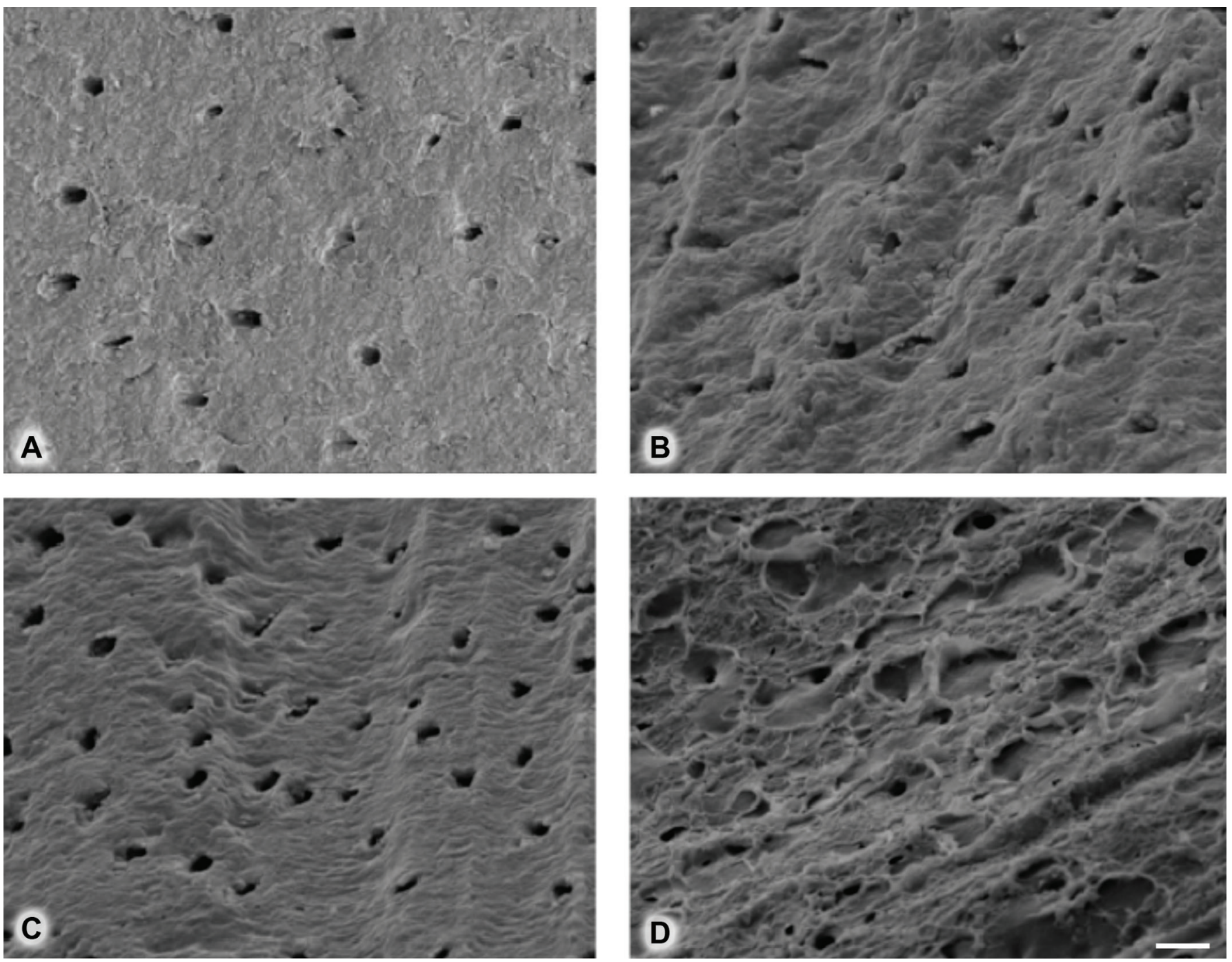

Figure 1. Morphological analysis on the central cervical region of the root fragments after different treatments. A- Control Group (GI). B - Citric Acid Group (GII). C - EDTA Group (GIII). D - Tetracycline Hydrochloride Group (GIV). Note the increased smear layer quantity in Figures A and D when compared to Figures B and C. Bar= 20 um. 
Table 1. Means and standard deviations for number of fibroblasts, in terms of root fragment conditioning and evaluation time.

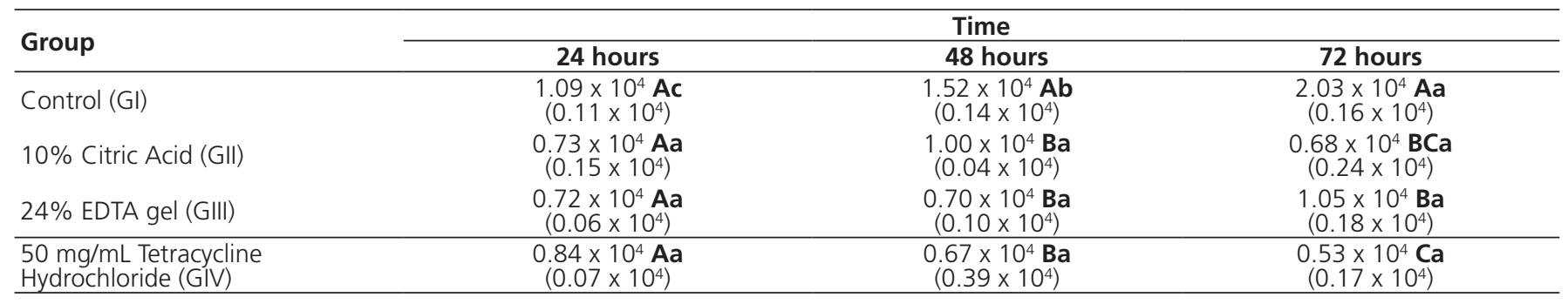

Note: Means (standard-deviation) followed by different upper- and lowercase letters indicate a significant intra- and intergroup difference, respectively (Anova e Tukey, alpha of 5\%).

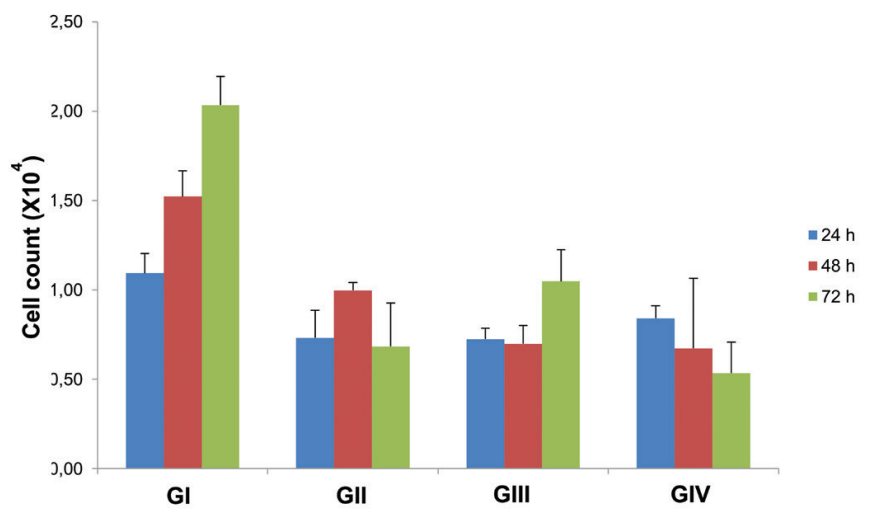

Figure 2. Cell growth of fibroblasts cell cultures after 24,48 and 72 h. Gl=control; Gll=10\% Citric Acid; GIII= 24\% EDTA gel; GIV= $50 \mathrm{mg} / \mathrm{mL}$ Tetracycline Hydrochloride. The error bars represent the standard deviations.

The use of subgingival tetracycline hydrochloride capsules has been shown to result in significant quantities of residue capable of obliterating the dentinal tubules ${ }^{20}$, which corroborates the findings of the current study, in which, $50 \mathrm{mg} / \mathrm{ml}$ Tetracycline Hydrochloride was applied for three minutes to the root surface. A significant amount of residual medication was observed covering the dentinal tubules, most likely due to the components present in the Tetracycline capsules not being completely dissolved, which could also produce an irregular surface following demineralization ${ }^{20}$.

In this study, when using 24\% EDTA gel, fibroblast proliferation after 72 hours was significantly higher $(p<0.05)$ than in the $50 \mathrm{mg} / \mathrm{ml}$ Tetracycline Hydrochloride group. However, the use of $24 \%$ EDTA and $10 \%$ Citric Acid did not reveal significant differences in terms of fibroblast proliferations, which is in agreement with other in vitro studies $5^{5,11,16,20}$, where both of the aforementioned chemical conditioners represent adequate substrates for fibroblast adhesion. Moreover, the current study revealed that after 72 hours, greater cell proliferation was seen for the control group compared to the groups submitted to chemical conditioning. These findings are similar to those by Baker et al. ${ }^{17}$, which suggests that these results are most likely due to the chemically treated root surfaces not having been rinsed sufficiently to remove the conditioning agents, resulting in cell, structural and biochemical damage, as well as platelet dysfunction. These findings are corroborated by an animal study using dogs by Zandim et al. ${ }^{13}$, who evaluated cement and bone formation, as well as epithelial migration over dehiscent areas after the application of a chemical root conditioner. They demonstrated a greater formation of root cement when EDTA had been applied, while the least bone formation was seen in the group treated with Tetracycline Hydrochloride. However, there was no significant difference between the groups.

Therefore, the results of the present study reveal that none of the chemical conditioners used removed the smear layer completely. However, the EDTA group was able to remove the largest amount of smear layer when compared to the other groups. Thus, it may be a suitable alternative for tissue repair in periodontics.

\section{CONCLUSION}

The results of the present study reveal that all demineralizing agents evaluated presented lower cell proliferation levels when compared to the control group. In addition none of the chemical conditioners used removed the smear layer completely.

\section{Acknowledgements}

The authors wish to thank Pollyanna Tombini Montaldi and Vanessa Araújo for their excellent technical expertise and assistance. 


\section{Collaborators}

The design of the present study and data analysis were conceived by Nayce Melinda Ferreira Lima and Elizabeth Ferreira Martinez. Manuscript elaboration and the final approval of the version submitted were done by all authors.

\section{REFERENCES}

1. Dayan S, Stashenko P, Niederman R, Kupper TS. Oral epithelial overexpression of IL-1 alpha causes periodontal disease. J Dent Res. 2004 Oct;83(10):786-90. doi: $10.1177 / 154405910408301010$

2. Pandit N, Malik R, Philips D. Tissue engineering: A new vista in periodontal regeneration. J Indian Soc Periodontol. 2011 Oct;15(4):328-37. doi: 10.4103/0972-124X.92564

3. Krayer JW, Leite, RS, Kirkwood KL. Non-Surgical Chemotherapeutic Treatment Strategies for the management of Periodontal diseases. Dent Clin North Am. 2010 Jan;54(1):1333. doi: 10.1016/j.cden.2009.08.010

4. Blomlof L, Jonsson B, Blomlof J, Lindskog S. A clinical study of root surface conditioning with an EDTA gel. Surgical periodontal treatment. Int J Periodontics Restorative Dent. 2000;20(6):566-73.

5. Blomlof JP, Blomlof LB, Lindskog SF. Smear layer formed by different root planning modalities and its removal by an ethylenediamenetetraacetic acid gel prepararion. Int J Periodontics Restorative Den. 1997;17(3):242-9

6. Houshmand B, Ghandi M, Nekoofar MH, Gholamii GhA, Tabor RK, Dummer PMH. SEM Analysis of MTAD Efficacy for Smear Layer Removal from Periodontally Affected Root Surfaces. J Dent (Tehran). 2011;8(4):157-64.

7. Ivanovski S. Periodontal regeneration. J Periodontol. 2005 Sep;76(9):1601-22. doi: 10.1902/jop.2005.76.9.1601

8. Babay N. Attachment of human gingival fibroblasts to periodontally involved root surface following scaling and/or etching procedures: a scanning electron microscopy study. Braz Dent J. 2001;12(1):17-21.

9. Kim TS, Schenk A, Lungeanu D, Reitmeir P, Eickholz P. Nonsurgical and surgical periodontal therapy in single-rooted teeth. Clin Oral Invest. 2007 Dec;11(4):391-9. doi: 10.1007/ s00784-007-0144-x

10. Shetty B, Dinesh S, Sechan H. Comparitive effects of tetracyclines and citric acid on dentin root surface of periodontally involve human teeth: A scanning electron microscope study. J Indian Soc Periodontol. 2008;12(1):8-15. doi: 10.4103/0972$124 \times .44090$

11. Vandana KL, Sadanand K, Cobb CM, Desai R. Effects of tetracycline, EDTA and citric acid application on fluorosed dentin and cementum surfaces: an in vitro study. Open Corrosion J. 2009; (2):88-95.

12. Ramseier CA, Rasperini G, Batia S, Giannobile WV. Advanced reconstructive technologies for periodontal tissue repair. Periodontology 2000. 2012;59:185-202.

13. Zandim DL, Leite FRM, Da Silva VC, Lopes BMV, Spolidorio LC, Sampaio JEC. Wound healing of dehiscence defects following different root conditioning modalities: an experimental study in dogs. Clin Oral Investig. 2013 Jul;17(6):1585-93. doi: 10.1007/ s00784-012-0848-4

14. Gamal AY. Enhanced b-tricalcium phosphate blended Clot Adhesion to EDTA biomodulated periodontally affected root surfaces: in vivo scanningelectron microscopy evaluation. J Periodontol. 2011 Nov;82(11):1587-95. doi: 10.1902/ jop.2011.110023

15. Tsurumaki JN, Souto BHM, Oliveira GJPL, Sampaio JEC, Marcantonio Júnior $E$, Marcantonio RAC. Effect of Instrumentation using curettes, piezoelectric ultrasonic scaler and $\mathrm{Er}, \mathrm{Cr}$ :YSGG laser on the morphology and adhesion of blood components on root surfaces - A SEM study. Braz Dent J. 2011:22(3):185-192.

16. Ruggeri Junior A, Prati C, Mazzoni A, Nucci C, Di Lenarda R, Mazzotti G, et al. Effects of citric acid and EDTA conditioning on exposed root dentin: An immunohistochemical analysis of collagen and proteoglycans. Arch Oral Biol. 2007 Jan;52(1):18. doi: 10.1016/j.archoralbio.2006.07.001

17. Baker DL, Stanley Pavlow SA, Wikesjö UM. Fibrin clot adhesion to dentin conditioned with protein constructs: an in vitro proofof-principle study. J Clin Periodontol. 2005 Jun;32(6):561-6.

18. Lee JY, Seol YJ, Park JR, Park YJ, Chung CP. Biological effects of a root conditioning agent for dentin surface modification in vitro. J Periodontal Implant Sci 2010 Aug;40(6):257-64. doi: 10.5051/jpis.2010.40.6.257

19. Suchetha A, Darshan BM, Prasad R, Ashit B. Root biomodification: a boon or bane? Indian J Stomatol. 2011;2(4):251-5.

20. Soares PBF, Castro CG, Branco CA, Magalhães D, Neto AJF, Soares CJ. Mechanical and acid root treatment on periodontally affected human teeth - a scanning electronic microscopy. Braz J Oral Sci. 2010 Jun;9(2):128-32.

21. Isik AG, Tarim B, Hafez AA, Yalcin FS, Onan U, Cox CF. A comparative scanning electron microscopic study characteristics or demineralized dentin root surface using different tetracycline $\mathrm{HCL}$ concentrations and applications times. J Periodontol. 2000 Feb;71(2):219-25. doi: 10.1902/jop.2000.71.2.219

22. Fontanari LA, Pinto SCS, Cavassim R, Spin-Neto R, Ishi EP, Sampaio JEC. Influence of dental exposure to oral environment on smear layer removal and collagen exhibition after using different conditioning agents. Braz Dent J. 2011;22(6):479485. doi: 10.1590/S0103-64402011000600007 